\title{
THE CONSTRUCTION OF AN IDEAL MOTHER AMID THE COVID 19 PANDEMIC : GENDER INJUSTICE EXPERIENCED BY CAREER WOMEN WHILE WORKING FROM HOME
}

\author{
Yelly Elanda \\ Jurusan Sosiologi, Fakultas Ilmu Sosial dan Ilmu Politik Universitas Wijaya Kusuma Surabaya, yelly.elanda@gmail.com

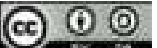 \\ (C)2021 by the authors. Submitted for possible open access publication under the terms and conditions \\ of the Creative Commons Attribution-ShareAlike 4.0 International License (CC-BY-SA) \\ license (https://creativecommons.org/licenses/by-sa/4.0/) \\ d. DOI : http://dx.doi.org/10.30983/ bumanisme.v5i1 \\ \begin{tabular}{l|l|l} 
Submission: November 5, 2020 & Revised : June 6, 2021 & Published: June 30, 2021
\end{tabular}
}

\begin{abstract}
Working from home is currently known as WFH (Work From Home). WFH seems to be something they want and expects for workers who are still active outside the home. But what about the WFH actors themselves? This discussion becomes intriguing when the construction of the ideal mother remains on patriarchal ideology, causing gender inequality. This paper uses a critical discourse analysis method by collecting articles about women who continue to carry out their roles as career women during the WFH period. Seventy-two articles appear in the google search engine when looking for WFH mothers during the covid 19 pandemics. However, from 72 articles, there are only 19 articles that talk about the stories of women who are doing WFH, tips and tricks on being a mother during WFH. In the article, the media constructs the ideal mother figure during the covid 19 pandemics. The ideal mother figure described by the media is a mother as a husband's servant, financial regulator, educator, child caretaker, and career woman. The construction of an ideal mother during this pandemic must carry out the four identities that are attached to her at once. The form of this identity is influenced by the ideology that coexists in society. These ideologies are patriarchal culture, ibuism, and capitalism.
\end{abstract}

Keywords: Ideal mother construction, COVID 19 pandemic, Work from home, Woman career, Gender injustice

\begin{abstract}
Abstrak
Bekerja di dalam rumah saat ini dikenal dengan istilah WFH (Work From Home). Bagi para pekerja yang masib terus beraktivitas di luar rumah, WFH seolah menjadi suatu hal yang diinginkan dan dibarapkan. Namun bagaimana bagi pelaku WFH itu sendiri? Pembahasan ini menjadi menarik ketika konstruksi ibu ideal masib berkutat pada ideologi patriarki sebingga menimbulkan ketidakadilan gender. Tulisan ini menggunakan metode analisis wacana kritis dengan mengumpulkan artikel tentang perempuan yang tetap menjalankan peran sebagai perempuan karier dan ibu rumah tangga selama masa WFH. Ada 72 artikel yang muncul dalam mesin pencari google ketika mencari ibu WFH masa pandemi covid 19. Namun dari 72 artikel hanya terdapat 19 artikel yang berbicara tentang curbatan para perempuan yang sedang melakukan WFH, tips dan trik menjadi ibu selama WFH. Dalam artikel tersebut, media mengkonstruksi sosok ibu ideal di tengah pandemi covid 19. Sosok ibu ideal yang digambarkan oleh media adalah ibu sebagai pelayan suami, pengatur keuangan, pendidik dan pengasuh anak, dan sebagai perempuan karier. Konstruksi ibu ideal di tengah pandemi ini harus bisa menjalankan empat identitas yang telah melekat pada dirinya sekaligus. Pembentukan identitas tersebut dipengarubi oleh ideologi yang ada pada masyarakat. Ideologi tersebut berdasar pada nilai patriarki, ibuisme dan kapitalisme.
\end{abstract}

Kata kunci: Konstruksi ibu ideal, Pandemi covid 19, Work from home, Perempuan karier, Ketidakadilan gender 


\section{Introduction}

The family is the smallest unit in society, so that family resilience is considered an essential factor for achieving national development. The family represents society because the family is the main agent in carrying out socialization, education, and socio-cultural functions. It is as what Wirdhana said about the eight functions of the family, including the functions of protection, love, affection, socio-cultural, religious, reproductive, economic, and environmental development. To carry out these functions, each family member has a role. The role is adjusted to the status or position in the family. There are roles of father, mother, and child that must be carried out to achieve success in carrying out its functions. This role continues to change according to the socio-cultural context that occurs in society. Adaptation of family members is needed to be able to adjust if there is a shock or change.

The COVID pandemic that has hit Indonesia since March 2020 has had a tremendous impact in all aspects. In the economic, social, political and cultural fields as a whole, families are also affected. Social changes that occur in families during the pandemic are fast, and the role of mothers is no exception. Career women who usually go to the office and leave their domestic tasks to institutions or alternate roles are now forced to return home. The government regulates the policy of carrying out all activities at home to prevent and curb the growth rate of the COVID-19 virus. Being a career woman, staying at home for a long is a dream that is very difficult to come true. Spending more time with family becomes a rare and expensive thing. Ideally, with this work from home policy, as a career woman and a mother, women will feel happy, gather with family, and spend time caring for and playing with their children and husbands. However, why do career women who do WFH at home feel stressed and confused?

A survey conducted by Komnas Perempuan from April to May 2020 in 34 provinces in Indonesia showed that the burden of household work increased and women worked twice as much as men. This condition causes women to experience stress. The pandemic conditions also caused household expenses to increase while the economic conditions decreased, they were worried about being fired, which also affected the relationship between couples. Women are more vulnerable to violence economically and psychologically ${ }^{1}$.

Based on the survey results, it can be concluded that the government's policy to stay at home causes women to experience a double burden during the pandemic: caring for, managing the household, working, and being a wife. Women experience a financial burden where their husbands are laid off (Termination of Employment) or get half the salary due to the implementation of a system of limiting hours and the number of workers so that women have to shoulder the responsibility of their husbands to increase family income. Women are vulnerable to domestic violence (Domestic Violence) and stress and mental disorders due to economic problems and excessive workload.

Another fact also shows that in various articles, the media always describe how many tasks a mother who is also a career woman must carry, domestic and public work responsibilities must be carried out in one time and place so that there is no separation of public spaces, and domestic. On the other hand, the substitute role or

1 Komnas Perempuan, "Kajian Dinamika Perubahan di Dalam Rumah Tangga Selama Covid 19 di 34 Provinsi di Indonesia", https://www.komnasperempuan.go.id diakses pada tanggal 17 Oktober 2020. 
institution that replaces the role and function of the family now suddenly has to stop due to this epidemic. The role of schools or educational institutions, daycare centers, assistants or household members now has to rely on a mother who is also doing WFH. However, is it true that the task is only the responsibility of a mother? In fact, several media and articles that review WFH always make the topic of ideal mothers an interesting issue.

The media that represents the sociocultural conditions of society seem to corner women with various responsibilities that must be carried out. The media constructs an ideal mother figure that will not be realized and will only cause a double burden with multiple roles for a mother who is doing WFH. The construction of the ideal mother embodied in the media causes gender inequality that women must experience. The media still uses the ideology of patriarchy, ibuism and capitalism in constructing the ideal mother figure. This paper will discuss the construction of the ideal mother based on patriarchal ideology that causes gender inequality, such as giving women a double or even multiple burden.

This study uses a critical paradigm in viewing a discourse, which means viewing reality as a pseudo reality. Social, political and economic forces construct reality. ${ }^{2}$ The purpose of the critical paradigm is to dismantle the myths that have been holding society together. The researcher's position must also be on the side of the oppressed so that the subaltern group can carry out emancipation. Researchers assume that the media is one of the public control tools used by the government. It is following what

\footnotetext{
${ }^{2}$ Eriyanto, (2005), Analisi Framing, Yogyakarta:
} LkiS
Littlejohn said about media being part of the ideological state apparatus. ${ }^{3}$

This study uses critical discourse analysis because the researcher wants to dismantle the ideology behind creating the ideal mother figure during the covid 19 pandemic. On the other hand, analytically, the researcher wants to show the process of making discourse that can construct news readers, especially women, to believe, carry out and spread constructions of ideal mother. Practically, the researcher wants to advocate for women who have been victims and are vulnerable to psychological, economic, cultural and political violence to be aware of and make efforts to emancipate themselves due to the formation of an ideal mother figure.

The subject of this research is online media that displays news about the complaints of women workers who are doing WFH during the covid 19 pandemic. There are 19 news articles from various online media in the google search engine, which displays news about complaints from women workers and mother doing WFH. Basically, there were 79 articles when the researcher typed the keyword WFH mother during the covid 19 pandemic. However, of the 79 articles, the researcher only found 19 articles that matched the qualifications set by the researcher. Researchers chose articles published in May to June because the government began to implement the WFH policy in that month. The criteria selected by the researchers are as follows:

1. The article talks about a woman who acts as a housewife and a career woman who is doing WFH

\footnotetext{
${ }^{3}$ W. Stephen Littlejohn, (2002), Theories of Human Communication, Belmont CA: Wadsworth Publishing Company h 213
} 
2. The article is the result of interviews with female WFH workers and housewives

3. The article talks about tips and tricks that can be done by female WFH workers as well as housewives

Critical discourse analysis used in this study is a social change approach using the Norman Fairclough model. Fairclough uses a social change approach that connects micro texts with macro community contexts through meso intermediaries, including text production, text distribution, and text consumption. Norman Fairclough builds a model that integrates together discourse analysis based on linguistics and social and political thought, and is generally integrated into social change. Fairclough divides discourse analysis into three dimensions: text, discourse practice, and socio-cultural practice. It is also stated by Fairclough that:

"CDA id consolidate here as 'three
dimensional' framework where the aim
is to map three separate forms of
analysis into one another. Analysis of
(spoken or written) language texts,
analysis of discourse practice (processes
of text production, distribution and
consumption) and analysis of discursive
events as instances of sociocultural
practice..."

This research is only focused on the micro level, namely on text analysis which includes representation, relations and identity. As Fairclough (1995:58) states, "Linguistic analysis is concerned with presences as well as absences in the texts that could include representations, categories of participant, constructions of participant identify or participant relations." 5 The text will be analyzed linguistically by looking at vocabulary,

${ }^{4}$ Fairclough, Norman, (1995), Critical Discourse Analysis:The Critical Study of Language, Singapore: Longman Singapore Publishers (Pte) Ltd h 2

${ }^{5}$ Norman Fairclough, (1995), Critical Discourse Analysis:The Critical Study of Language h 58 semantics and sentence structure. He also includes coherence and cohesiveness. This analysis will see how the words or sentences are combined to form understanding. The elements used in analyzing the text are used to see three problems, first, at the ideational level, which sees text as a representation of an object. This analysis wants to see if an object is displayed likely to carry a certain ideological content. Second, the relationship whose analysis results will show how journalists and readers are positioned by positioning readers and journalists in a text. Third, identity whose analysis results will refer to the construction of the identities of journalists and readers and how these personalities and identities are to be presented. ${ }^{6}$ By only examining at the text level, ideology can be seen from the use of vocabulary, the grammar used, how to position the dominant group and the other group.

\section{Discussion}

\section{Women and Family Dynamics}

According to Murdock, family is a social group that lives together and carries out economic and reproductive activities. ${ }^{7}$ In the family there is a division of status and roles so that it affects the division of labor or roles that must be carried out. According to Martono, the relationship in the family is based on emotion because there are blood ties and live in the same environment (household). The family is formed to carry out its functions and roles. The family has several functions, including economic function (fulfillment of needs), reproductive function (fulfillment of biological needs), psychological function (distribution of

${ }^{6}$ Eriyanto, (2005), Analisi Framing ,h 286-287

${ }^{7}$ Haralambos and Holborn, (2004), Sociology: Themes and Perspective $6^{\text {th }}$ Edition, London: Harper Collins Publisher 
affection), social function (place of socialization and social mobility), educational function (distribution of skills, knowledge). ${ }^{8}$ Basically, the function of the family is the five things mentioned above, but along with the development of society, the function of the family experiences a shift in meaning and many factors influence it.

Families in Indonesia still have a patriarchal ideology, this is influenced by cultural, religious and traditional factors that are taught through education, both formal and informal as well as through the media.' The media has indirectly provided a picture of the ideal family and the division of labor among family members. Mothers and wives have an obligation to take care of domestic household affairs and fathers have a role to earn the main living. Although many women also work to supplement the family's economy, women are still considered responsible for domestic affairs and carry out their traditional functions to maintain the culture and traditions of their ancestors. Women experience a double burden because they have to carry out their main tasks while working to increase income for the family. ${ }^{10}$

In an agrarian society, the involvement of women in the realm of production is extensive. This is because work in the family is a shared job, the whole family is involved in it. There is no thought about the advantages and disadvantages of doing work together, they are delighted and enjoy the work. Women in an agrarian society have a huge role, they are involved in the domestic

\footnotetext{
${ }^{8}$ Nanang Martono, (2018), Sosiologi Perubahan Sosial, Depok: Rajawali Press

${ }^{9}$ Hatmadji\& Utomo, (2004), Empowerment of Indonesia Women: Family, Reproductive Health, Employment and Migration, Jakarta: Universitas Indonesia

${ }^{10}$ Amorisa Wiratri, Menilik Ulang Arti Keluarga pada Masyarakat Indonesia, Jurnal Kependudukan Indonesia, Vol.13, No.1, Juni 2018
}

sphere and help their husbands in the fields. Maids cannot replace the role of women in the domestic sphere because this will burden the husband who has to provide additional costs. $^{11}$

In industrial society, the family has lost some of its functions, but it remains an important institution. The role of the family only experienced adaptation to the conditions of industrial society. One of the things that has changed is the role of the wife, which was initially only in the domestic sector, now wives and mothers have penetrated the public world. According to Durkheim, demographic factors affect the increasingly specific division of labor. Families experience structural differentiation so that there is an increase in the functions and roles of family members. Marx's analysis states that the heavy economic burden forces women as wives also to earn a living. Self-actualization or fulfillment of selfexistence also causes women to begin to show their abilities in the public sphere. The increasing level of education also encourages structural differentiation. ${ }^{12}$

This structural differentiation has led to the existence of an institution that replaces the function and role of the family, such as raising children, washing clothes, cooking and other roles that women usually perform. This is in line with what Fletcher said, in modern society, the family continues to carry out its function, but other institutions that increase its function and existence are fundamental. ${ }^{13}$ The role of

11 Dina Dwikurniarini, Peranan Perempuan di Luar Rumah Tangga dalam Perspektif Historis, Mozaik: Jurnal Ilmu-Ilmu sosial dan Humaniora Vol.2, No.1, 2007

12 Nanang Martono, (2018), Sosiologi Perubahan Sosial

${ }^{13}$ Haralambos and Holborn, (2004), Sociology: Themes and Perspective $6^{\text {th }}$ Edition 
parenting is transferred to other parties so that the family as the smallest unit of society to carry out socialization is not optimal and educational institutions tend to take more roles than parents. With this institution replacing the role of the family, women feel helped especially as career women who spend much time working.

Structural differentiation that previously had been running stably, suddenly had to undergo rapid changes due to the covid 19 pandemic. Educational institutions such as schools were abolished, children had to study at home, parents also had to do their work from home, child care centers had to closed, the ART also suddenly had to be sent home. As a result of this incident, women had to return to their domestic roles while simultaneously carrying out their public roles. Multiple roles of women, conflict in the role of women in the family occurs quickly and must be at the same time and space, namely at home. Women's roles as wives, mothers and workers must be carried out by themselves, without the help of substitute roles as before. It is one of the stress factors for mothers during WFH and even becomes one of the triggers for family conflicts.

\section{Media and the Ideal Mother's Identity in the Midst of the Covid 19 Pandemic}

The formation of maternal identity is the result of discourse practice and discourse formation. Every era the ideal mother figure experiences its dynamics. It is influenced by the discourse that develops in the community, especially the media in spreading the discourse. ${ }^{14}$ The media is a representation of the culture that exists in society. Foucault identifies various historical conditions and rules that determine the formation of an orderly way of talking about

Yogyakarta: Wacana objects, namely discursive practice and discourse formation. Based on the results of Douglas and Michaels research, the concept of the ideal mother or motherhood in the 21 st century is a mother who can carry out dual roles, namely being successful in the domestic sphere (having children and having free time to make healthy food) and the career. ${ }^{15}$ This is also in line with what Hays said that the ideal mother is a mother who is willing to raise and spend time and energy raising children. ${ }^{16}$ Alyson Schafer in his book Breaking The Good Mom Myth mentions that many define the ideal mother as a mother who is responsible for what the child does, from achievement to behavior.

From some of these research results, the ideal mother figure is described as a person who prioritizes and is responsible for children and has to move in the public sphere, namely being a career woman. Having multiple roles and running an ideal mother figure is considered very difficult for women to carry out. Universally, motherhood is idealized as the pinnacle of a woman's achievements, dreams and ambitions. $^{17}$

During the COVID-19 pandemic, there are changes in social, economic, political and cultural conditions that affect the role of a mother. Politically, there are policies for work from home, study at home and there are layoffs. This certainly affects the existing economic, social and cultural conditions, women also experience various problems and changes due to the conditions of this pandemic. First, there is a double burden where women have to take care of, manage the household, work and act as a

15 J.S. Douglas \& W. M. Michaels, (2004), The Mommy Myth, Free Press

${ }^{16}$ S. Hays, S, (1998), The Cultural Contradictions of Motherhood, Yale University Press

17 Dorothy Hammond dan Alta Jablow, (1976), Women in Coltures of The World, USA: Ricmond 
wife at the same time. Second, women bear the financial burden where there are many cases of layoffs and reduced working hours so that it also affects family income. Women have to rack their brains and mobilize energy to restore the family's economic condition. Third, the psychological burden where women are depressed with all the demands that must be met by themselves, both as a mother, wife and worker. Fourth, in such conditions, women become targets of emotional outlets for their husbands, cases of domestic violence are increasing and women are vulnerable to experiencing domestic violence. Fifth, various difficult conditions faced by the family, women are more likely to experience stress and mental health disorders.

The conditions experienced by these women are illustrated in portraits taken by several media. There are stories about women doing WFH while also carrying out their domestic activities in some media. In its reporting, the media does present the complaints of women who work, become mothers and act as wives simultaneously and in the same space, namely the house. However, at that time, the media actually also framed news about the ideal mother, wife and worker when doing WFH. Some of the changes that have occurred have also encouraged the media to form a discourse about the ideal mother figure or motherhood. Being an ideal mother when doing WFH is considered very difficult and becomes a burden for women. During this pandemic, there is an ideal mother figure that the media have just discussed. It includes a mother as a financial planner, a mother as an educator and child caretaker, a mother as a husband's servant, and a career woman.

\section{Mother as a Financial Planner}

This pandemic period is a tough time for workers. Many workers were suddenly laid off or laid off. The government's policy regarding PSBB also affects economic conditions. Although much social assistance has been disbursed, the economic condition of the families affected by COVID-19 has decreased. Many women complain that spending during the pandemic is increasing because they have to provide snacks for their children while studying and do not get bored while at home. Cooking rituals during the pandemic have become mandatory for women to ensure food hygiene and fulfill their family's nutrition because pandemic conditions require us to be more aware of health. Women also have to provide vitamins for their families to have a good immune system, which increases expenses.

The current pandemic condition can be said to be an emergency situation where in an emergency, wives must rush to take on the husband's role as the backbone of the family, some selling and becoming household members or freelancers. Another way that women have done with the COVID-19 pandemic is to manage family finances, reduce spending. Women have indeed been given space to enter the public sphere by leaving home, but from year to year (for 20 years), many female workers have occupied as workers or unskilled laborers in agriculture/plantation, accommodation and restaurant services, and community and social services. and individuals. ${ }^{18}$ This condition shows the existence of gender inequality which can be seen from (1) socio-cultural roots (2) the

18 Badan Pusat Statistik, "Keadaan Angkatan Kerja di Indonesia”, https://www.bps.go.id/ diakses tanggal 25 Oktober 2020 
process of giving meaning and maintaining the inequality is continuous (3) the role of the market in the job segmentation process. ${ }^{19}$

The provision of stigma or segmentation in certain jobs also affects the placement of women in work, both in the work environment and in the household/family realm. Men are identical with production activities and women in the realm of consumption. These differences indicate the existence of power negotiations carried out by men and women. Consumption is seen in production because men control the role of women because men manage production. ${ }^{20}$ Therefore, financial management is in the wife's hands and the main provider or money maker is the husband. Expenditures made by the wife are under the husband's control, meaning that the income provided by the husband must meet the needs of the family, women must be good at managing finances. Such construction forces women to earn money to meet the needs of the family so that if the woman works then her status is only to supplement family income or help her husband, the position of women as workers is sidelined.

\section{Mother as Educator and Child Caregiver}

The WFH (Work From Home) policy coincides with the SFH (School From Home) policy. With this policy, all family members gather together at home. They carry out activities that are usually done outside the home are moved into the house. Parents' office work is taken home, done at home. Children's work from school is also done at home during this pandemic. During

19 Irwan Abdullah, (1995), Reproduksi Ketimpangan Gender Partisipasi Wanita dalam Bidang Ekonomi, Jakarta: LP3ES

20 Kartini Syahrir, (1985), Wanita: Beberapa Catatan Antropologi, Jakarta: LP3ES
WFH, there were many complaints from working women who had to become teachers. Many children ask to be accompanied by their mother while studying, the tasks given by the school are quite a lot and working women find it difficult with their children's schoolwork, especially if they have several children who need learning assistance at the same time. Many working women feel pressured because they are not ready for the WFH and SFH conditions that require them to work and assist their children in studying simultaneously. Such conditions make it difficult for working mothers to manage their time and they become stressed because there is more work to be done.

There are several tips reported by the media in accompanying children during $\mathrm{SFH}$, namely collaborating with partners to get involved. However, in several news reports containing complaints from working women, there is no information regarding the participation of spouses in accompanying children to study. In the presented news, there is a lot about the difficulty of working women who accompany their children to study when the mothers work in WFH and the children are in SFH. The psychological burden felt by women is inseparable from the social construction of the ideal mother figure that mothers must accompany their children. The concept of intensive mothering describes the ideal mother figure where intensive mothering emphasizes mothers who must always be around their children to create emotional closeness with their children. ${ }^{21}$

Changes and debates about the ideal mother figure continue to roll over time. Before independence, the ideal mother

${ }^{21}$ Putri Limilia, Konstruksi Sosial Ibu Bekerja VS Ibu Rumah Tangga, Semiotika: Jurnal Komunikasi, Vol. 10 No.1 Juni 2016 
remained at home raising her child. What we call as an ideal mother has changed along with the opening of the education system for women and entering the world of work. The concept of an ideal mother is a mother who is successful outside the home without forgetting her duty to educate children by entrusting her children to her extended family. The shift in the concept of the ideal mother recently has also returned to laying off women to accompany children but still making money. It happens because there are many cases of ART doing negligence and there are many cases of violence. ${ }^{22}$

In the end, although women have entered the public sphere, work and make money. However, its existence is only considered as a support or additional family economy. Women cannot be separated from their duties in the domestic sphere, especially in nurturing, raising and educating children. Caring and nurturing are traditional traits that are always associated with women. ${ }^{23}$ This cannot be separated from the culture and social construction of the ideal mother figure. ${ }^{24}$ The social construction of the ideal mother also regulates the responsibilities, roles and tasks that a mother must carry out. ${ }^{25}$ Throughout history, the discourse on the ideal mother figure cannot be separated from the role and responsibility to raise and educate children, even though they are successful and work outside the

22 Putri Limilia, Putri, Konstruksi Sosial Ibu Bekerja VS Ibu Rumah Tangga

${ }^{23}$ Rosemarie Putnam Tong, (2006), Feminist Though, Yogyakarta: Jalasutra

24 L. Shari Thurer, (1995), The Myths of Motherhood, United States of America:

Penguin Books dan G. Bridget Therriault, (2014) Moms Gone Social: A Critical Thematic Analysis of Mommy Facebooking And Its Effect On Motherhood Identities And The "Good" Mother Ideal, Disertation. United States of America: Villanova University

${ }^{25}$ Putri Limilia, Konstruksi Sosial Ibu Bekerja VS Ibu Rumah Tangga
homeAt the time of WFH, women even more complained and were oppressed because they were burdened with domestic tasks in educating children, which educational institutions or institutions usually carry out. In this pandemic situation, it is hoped that couples will have the awareness to partner in parenting, but that does not happen because of the perpetuation of the ideal mother figure. Gender division of labor is still lasting and running. This is in line with what the nurture theory says that sexual division is a product of the social environment that is passed down continuously through socialization. ${ }^{26}$ The social and cultural construction of the ideal mother figure is still profoundly rooted even though several feminist movements and the rapid development of knowledge about feminist studies have been developed. The task of taking care of children is still the responsibility of women. In a patriarchal society, women are expected to be able to look after, nurture and care for children because women can only do this. ${ }^{27}$

\section{Mother as Husband's Pleaser}

The role of women is grouped into two, namely the role of tradition and the role of transition. ${ }^{28}$ The traditional role includes the role of wife and mother who manages the household. Transitional roles relate to their roles as workers, community members and development people. As wives, women must accompany, serve and even serve their husbands, arrange, prepare and serve nutritious food for the family. As family members, women are obliged to educate

\footnotetext{
${ }^{26}$ Arif Budiman, (1981), Pembagian Kerja Secara Seksual, Jakarta: PT Gramedia

27 Andrea O'Reilly, (2010), Encyclopedia of Motherhood, California : Sage Publications

28 Handewi P. Suliem, (1992), Potensi dan Partisipasi Wanita dalam Kegiatan Ekonomi Pedesaan, Jakarta: LP3ES
} 
children, clean the house. Carrying out a transitional role, women can be actively involved in economic activities according to their abilities, education and opportunities, and willingness. The traditional role is the result of social construction and has been entrenched from generation to generation with regard to domestic duties, namely as mothers and wives. The transitional role is the role of women to be actively involved in activities outside the home.

Basically, the husband and wife relationship is a form of collaboration, equal and a partner in building a household. However, patriarchal culture causes the formation of social constructions regarding the division of labor. Men tend to dominate women and women tend to be objects. As Bourdieu said, "The inequality that occurs is very radical between men who are the subjects and women who are the objects of exchange; between men who are in charge and masters of production and reproduction and women who are only products undergoing transformation as a result of the work of production and reproduction". ${ }^{29}$ From this statement, it becomes a natural thing or is considered normal if women have to serve their husbands, women must serve the masters who are responsible for the production and reproduction process.

In domestic life, it turns out that patriarchal culture is still rooted and causes inequality in the position of husband and wife. Men tend to be more potent in the family than women. Masculinity which is identical to men makes women look weak and women experience the consequences of the power exercised by men. The consequence of this is that men dominate women in relationships and take advantage

\footnotetext{
${ }^{29}$ Pierre Bourdieu, (2010), Dominasi Maskulin, Yogyakarta: Jalasutra h 65
}

of both personal and sexual services, make decisions in the family, control money and expenses and other things. ${ }^{30}$ During the WFH period, many people think they will feel free time without pressure, but who would have thought that working women would actually work more times than usual. These women workers have to serve their husbands because they have "masters" namely husbands and children who are also staying at home. Domestic duties make women workers to do more work than their public duties. His public duties were only underestimated because the full responsibility for production was in the hands of men. Working women are only considered as assistants in the production process.

On the other hand, women must continue to work in order to be able to meet family needs and avoid layoffs. Many companies have unilaterally terminated employment during the pandemic, especially for women. The position of women is a position that is prone to being laid off because women's work is still underestimated. Women so far have occupied positions that are less strategic and not central. So, women workers are targeted and prone to being laid off by their companies. During WFH, women workers have hopes of enjoying their own time (me time), relaxing, relaxing and can have some activities that can explore their abilities to show their existence and avoid psychological, economic, cultural and physical pressures. Women also expect their partners to build equal relationships, help with housework and do it together to ease the burden on women workers. They want to be supported and understood by their

${ }^{30}$ M. Susan Shaw dan Janet Lee (ed), (2012), Women's Voices, Feminist Visions : Classic And Temporary Readings. New York : McGraw-Hill 
partners in dealing with gender inequality that has been holding them back.

\section{Mother as a Career Woman}

The participation of women in the public sector continues to grow from time to time. The female labor force participation rate (TPAK) in 1980 was 32.43\%, in 1990 it was $38.79 \%$ and in 2014 it had become $50.22 \%$ (Rahayu, 2015). This change is none other than the shift in values and norms concerning changes in the role of institutions. However, the involvement of women in the public sphere only occupies a non-strategic position, family or unpaid workers are still dominated by women and jobs that occupy strategic positions in decision-making are still mostly held by men. ${ }^{31}$

The large number of women who are already working does not mean that the existing patriarchal value has started to disappear, instead women have to bear the double burden of playing the role of workers and housewives. The perception of the ideal mother that is still valid so far is the success of women in the family and work. The success of the family is still the responsibility of women as a mother. ${ }^{32}$ The double burden that women must bear adds to the oppression and dilemma for women. When she becomes a career woman, women also still feel that their body is no longer theirs. The capitalists exploit their bodies, they place women in vulnerable sectors so that they are considered weak, incompetent and paid cheaply. This working woman's body is disciplined, controlled and controlled by the rules of the capitalists. It is as stated by Faqih that:

31 Irwan Abdullah, (2001), Seks, Gender dan Reproduksi Kekuasaan, Yogyakarta:Tarawang Press.

32 Nurul Hidayati, Beban Ganda Perempuan Bekerja. Muwazah: Jurnal Kajian Gender, Vol.7, No.2, Desember 2015
"In the era of capitalism, women were exploited in various ways. First, women are required to return home to take care of and serve their husbands after work. Second, women become cheap laborers. Third, the inclusion of women in the capitalist system is considered profitable because firstly, women's wages are cheaper. Both women workers are considered as unlimited reserve workers. Therefore their enemy is capitalism". 33

Amid the COVID-19 pandemic, female workers are required to carry out their public duties in the domestic space. These women workers experience confusion because they are not able to organize and share public and domestic tasks together. At the same time, substitute institutions for family roles such as schools, child care and ART are no longer operating. On the other hand, the company tries to find fault with the women workers so that the capitalists have an alibi to reduce their salaries or even lay off their workers. Working women are also required to be able to play the role of an ideal mother who is widely echoed by the media and is the hope of the patriarchal society. Currently, female workers who are doing WFH experience increasing oppression. This condition seems to corner working women to choose between the domestic and public domains. The solution so that women can get out of this condition is to shake hands with their partners to build equal relations in domestic life.

Ideal Mother Construction During the Covid 19 Pandemic

${ }^{33}$ Mansour Fakih, (2012), Analisis Gender dan Transformasi Sosial,Yogyakarta: Pustaka Pelajar 
The construction of the ideal mother during the COVID-19 pandemic has increasingly convinced women not to carry out domestic and public roles together. Basically, the construction of the ideal mother figure that is described and expected by patriarchal society cannot be achieved. There is no ideal mother figure as described by the media, namely the mother as an educator, child caretaker, husband's servant, financial manager, and career woman. As human beings, women cannot perform multiple roles perfectly. However, women are still burdened with domestic and public tasks in the midst of this crisis-prone pandemic condition, not only the economic crisis, but also mental and physical.

This discourse about the ideal mother figure is a way of disciplining the female body, which is physical and mental. The discourse about the ideal mother figure during WFH is a form of physical and mental discipline. Barker states that discipline contains the arrangement of subjects in a certain space through the practice of separation, training and standardization. It produces subjects by categorizing and naming them in a hierarchical order through rationality of efficiency, productivity and normalization. In forming the ideal mother's identity some values form the basis of the ideal mother's construction, including the values of patriarchy, capitalism and motherhood.

\section{Construction of the Ideal Mother Based on Patriarchal Values}

The discourse on the ideal mother figure is one of the patriarchal cultural practices that continues to be applied. This gender inequality has caused a double burden for women to still look perfect in the domestic and public spheres. During this pandemic, the ideal mother figure is being promoted, expected by husbands and children. Women seem to be a source of solace amid a crisis-prone pandemic. Economic vulnerability corners women to be able to manage finances and even become the foundation of the family's economy. However, on the other hand, domestic tasks are getting tougher because institutions that replace roles such as day care centers, schools are closed, ART are sent home or disabled. The patriarchal culture still wants women to stay at home, dwelling in the domestic sphere.

Feminist spirit has indeed caused women to be able to work, become career women. However, it turns out that the role of these women workers is only considered as an additional task or economic support, its existence is only as a sideline. Meanwhile, the main task in the domestic sphere is still the benchmark for a woman's success. Being a nanny and educator for children, managing finances and serving husbands remains the main task of working women. The perspective that men still dominate causes women to experience oppression to continue to be an ideal figure. This is as stated by Kamla Bashin that patriarchal culture is an ideology that places men above women and women are controlled and dominated by men. (Bashin, 1996).

\section{Construction of the Ideal Mother Based on Capitalism}

The ideology behind the formation of the ideal mother discourse is also supported by capitalism. The formation of the ideal mother figure has defined, created and formed power relations. The discourse of creating an ideal mother figure is played by capitalism for profit. Working women are seen as people who can lead successful career lives so that capitalists can pay women at low prices. This is following what Abdullah said that women are instruments of capitalism, women are required to do the 
same work as men but the wages given are lower. Access for women to various jobs is also hindered due to various interests. ${ }^{34}$

In this WFH condition, women workers also have to be responsible for work matters and there is no reason for women workers not to fulfill their responsibilities. The formation of this ideal mother discourse is a collection of power relations systems. Power relations that use feminist ideology to continue to work in the public sphere. However, they are also exploited by the capitalists. WFH takes more working hours than has been set. On the other hand, there are power relations that move in the sociocultural system regarding patriarchal culture. Domestic responsibilities are still centered on women. The continuous oppression given to women has made women vulnerable psychologically, physically, socially, economically and politically, especially in the midst of this COVID-19 pandemic.

\section{Construction of the Ideal Mother Based on the Concept of Ibuism}

The term motherhood is equated with ibuism in Indonesia and has a vital role in supporting the state's goals and continuing the descent. ${ }^{35}$ At the end of the New Order era, the term state motherhood emerged. This state ibuism is a tool to mobilize programs run by the government, including the family planning program and the NKKBS (Norma Keluarga Kecil Bahagia). The New Order also emphasized the morality of motherhood as husband and

\footnotetext{
${ }^{34}$ Irwan Abdullah, (2001), Seks, Gender dan Reproduksi Kekuasaan

${ }^{35}$ Deshinta Asriani, Being Mother: Comparative Study of the Contested Motherbood between South Korea and Indonesia. IJMESH: International Journal of Management, Interpreneurship, Social Science and Humanities, Vol 1, No1 2017
}

wife and state motherhood. ${ }^{36}$ In the social and cultural aspect, the mother has a predetermined task by prioritizing the child's interests rather than herself and is perceived as loving and patient. ${ }^{37}$

The term ibuism was first coined during the New Order era, but to this day the idea has stuck and has become an ideology. The hegemony of the ideal mother in the household is being able to act as a mother and wife. Women are imagined as life companions for their husbands, giving birth to a nation, educating children. In addition, women are also encouraged to support economic industrialization in Indonesia by earning additional income and carrying out their duties as members of the community. ${ }^{38}$ State motherism is a combination of feudalism and capitalism. ${ }^{39}$ (Suryakusuma, 2015). The sexual division of labor is the result of the construction of feudalism because this will affect the position of men and women. women still experience discrimination in the division of labor both domestically and in terms of work (career). Capitalism deliberately puts a stereotype on women to pay women cheaper and puts them in a lower position.

During this time of the pandemic, which has brought its own challenges for working women, high hopes are placed. The social construction that is led by the media seems to reaffirm the ideology of

${ }^{36}$ Ruth Indiah Rahayu dan Aprilia Runi Iqraa, Rekonstruksi Pemahaman Kebangsaan: Percakapan tentang Perempuan dan Kebangsaan, Jurnal Perempuan, Vo.23, No.3, Agustus 2018

37 Yati Afianti, Negotiating Motherhood: The Difficulties And Challenges Of Rural First Time Mothers In Parung,West Java. Makara: Journal of Health Reseach, Vol 6, No 2, Desember 2002

38 Deshinta Asriani, Being Mother: Comparative Study of the Contested Motherhood between South Korea and Indonesia.

39 Julia Suryakusuma, Julia. Ibuisme Negara adalah Perkawinan antara Feodalisme dan Kapitalisme, Jurnal Perempuan, 7 Oktober 2015. 
motherhood or ibuism or motherhood. So far, the role of women as mothers has undergone a shift with the existence of substitute roles or institutions such as household members, child care centers, schools, others. However, with this policy during this pandemic, women are being domesticated again. The term WFH seems just to change places of work, but not for women. During WFH, children also have to SFH and husbands also do WFH, it becomes a burden for women. women must return to carrying out their duties as a wife, mother and worker at the same time and in the same place. This shows that motherhood as an institutional concept is still very strong. Men or a patriarchal system controls women in these institutions. ${ }^{40}$ (Rich, 1986).

\section{Conclusion}

The discourse about the ideal mother figure is a discourse echoed for working women to continue to be ideal mother figures to carry out their domestic duties. This discourse has oppressed working women during the COVID-19 pandemic. Working women are made more vulnerable in the midst of a crisis by being an ideal mother figure. The identity of the ideal mother figure pinned to women is a financial regulator, educator and child caretaker, husband's servant and being a career woman. The identity embedded in this ideal mother has caused working women to experience gender injustice, including double or even multiple burdens, mental or psychological pressure, subordination and marginalization.

The state, capitalists, media and society unite to form a system of power relations to oppress women by constructing

40 Adrienne Rich, (1986), of Women Born: Motherhood as Experience and Institution, New York and London: Norton Company the ideal mother figure in society. Capitalism permeates women's lives through WFH work rules during the covid pandemic with lower salaries and vulnerability to layoffs. Patriarchal values are incarnated in a sociocultural system that emphasizes women as those in charge of domestic tasks. The ideology of ibuism makes women have to bear their obligations as a mother, wife and additional income earner. Rapid social changes during this pandemic condition make women more vulnerable to exploitation and undergo a double and even double burden because they carry out domestic and public tasks simultaneously and location when the WFH and SFH policies are in place.

During this pandemic, people are required to empathize with each other and work together to strengthen and support each other. The family should build a partnership between husband and wife, there is no longer a division of labor based on gender. Roles in carrying out family functions can be exchanged, those that cannot are what has become natural, like childbirth, pregnancy and breastfeeding. Companies or capitalists should also support women workers by providing relief during WFH without reducing their main duties or responsibilities. Before the pandemic, the double burden borne by women workers was lighter with educational institutions and child care services as well as ART. However, the oppression of women is increasingly pressing due to the stay-at-home policy and the impact of the COVID-19 outbreak. It causes many cases of layoffs and WFH. Everyone must feel pressured during this pandemic condition, but the construction of the ideal mother has made working women more oppressed and experience a double and even double burden due to gender inequality. In a situation like this, women should get more sympathy and attention 
because various ideologies confine working women.

\section{Bibliography}

\section{Journal}

Afianti, Yati, Negotiating Motherhood: The Difficulties And Challenges of Rural First Time Mothers In Parung,West Java. Makara: Journal of Health Reseach, Vol 6, No 2, Desember 2002.

Asriani, Deshinta, Being Mother: Comparative Study of the Contested Motherhood between South Korea and Indonesia. IJMESH: International Journal of Management, Interpreneurship, Social Science and Humanities, Vol 1, No1 2017

Dwikurniarini, Dina, Peranan Perempuan di Luar Rumah Tangga dalam Perspektif Historis, Mozaik: Jurnal Ilmu-Ilmu sosial dan Humaniora Vol.2, No.1, 2007

Hidayati, Nurul. Beban Ganda Perempuan Bekerja. Muwazah: Jurnal kajian Gender, Vol.7, No.2, Desember 2015

Limilia, Putri dan Prasanti, Ditha, Representasi Ibu Bekerja VS Perempuan di Media Online. Kafa'ah: Center For Gender and Child Studies, Vol.6, No.2, 2016.

Limilia, Putri, Konstruksi Sosial Ibu Bekerja VS Ibu Rumah Tangga, Semiotika: Jurnal Komunikasi, Vol. 10 No.1 Juni 2016

Rahayu, Wiji Angger, Perempuan dan Belenggu Peran Kultural, Jurnal Perempuan, 29 Januari 2015.

Rahayu, Indiah Ruth dan Iqraa Runi Aprilia, Rekonstruksi Pemahaman Kebangsaan: Percakapan tentang Perempuan dan Kebangsaan, Jurnal Perempuan, Vol.23, No.3, Agustus 2018.
Suryakusuma, Julia. Ibuisme Negara adalah Perkawinan antara Feodalisme dan Kapitalisme, Jurnal Perempuan, 7 Oktober 2015.

Wiratri, Amorisa, Menilik Ulang Arti Keluarga pada Masyarakat Indonesia, Jurnal Kependudukan Indonesia, Vol.13, No.1, Juni 2018.

\section{Buku Teks}

Abdullah, Irwan, (1995), Reproduksi Ketimpangan Gender Partisipasi Perempuan dalam Bidang Ekonomi, Jakarta: LP3ES

Abdullah, Irwan, (2001), Sekes, Gender dan Reproduksi Kekuasaan, Yogyakarta:Tarawang Press.

Barker, Chris, (2013), Cultural Studies, Yogyakarta: Wacana

Bashin, Kamla, (1996), Menggugat Patriarki, Yogyakarta: Yayasan Bentang Budaya

Bourdieu, Piere, (2010), Dominasi Maskulin, Yogyakarta: Jalasutra

Budiman, Arif (1981,) Pembagian Kerja Secara Seksual, Jakarta: PT Gramedia

Douglas, S. J., \& Michaels, M. W, (2004), The Mommy Myth, Free Press

Eriyanto, (2005), Analisi Framing ,Yogyakarta: LkiS

Fairclough, Norman, (1995), Critical Discourse Analysis:The Critical Study of Language, Singapore: Longman Singapore Publishers (Pte) Ltd.

Fakih, Mansour, (2012), Analisis Gender dan Transformasi Sosial ,Yogyakarta: Pustaka Pelajar

Hammond, Dorothy dan Jablow Alta, (1976), Women in Coltures of The World, USA: Ricmond 
Haralambos and Holborn, (2004), Sociology: Themes and Perspective $6^{\text {th }}$ Edition, London: Harper Collins Publisher

Hatmadji\& Utomo, (2004), Empowerment of Indonesia Women: Family, Reproductive Health, Employment and Migration, Jakarta: Universitas Indonesia

Hays, S, (1998), The Cultural Contradictions of Motherbood, Yale University Press.

Istiati, (2010), Hubungan Fungsi keluarga dengan Kecemasan pada lanjut Usia, Surakarta: UNS

Kamla, Bhasin, (1996), Menggugat Patriarki Pengantar Tentang Persoalan Dominasi Terbadap Kaum Perempuan, Yogyakarta: Bentang Budaya

Littlejohn, Stephen W, (2002), Theories of Human Communication, Belmont CA: Wadsworth Publishing Company

Martono, Nanang, (2018), Sosiologi Perubaban Sosial, Depok: Rajawali Press

O’Reilly, Andrea, (2010), Encyclopedia of Motherhood, California : Sage Publications

Rich, Adrienne, (1986), of Women Born: Motherhood as Experience and Institution, New York and London: Norton Company

Shaw, Susan M. dan Janet Lee (ed), (2012), Women's Voices, Feminist Visions : Classic And Temporary Readings. New York : McGraw-Hill

Suliem, P. Handewi, (1992), Potensi dan Partisipasi Perempuan dalam Kegiatan Ekonomi Pedesaan, Jakarta: LP3ES

Syahrir, Kartini, (1985), Perempuan: Beberapa Catatan Antropologi, Jakarta: LP3ES

Therriault, Bridget G, ( 2014) Moms Gone Social: A Critical Thematic Analysis of Mommy Facebooking And Its Effect On
Motherhood Identities And The "Good" Mother Ideal, Disertation. United States of America: Villanova University

Thurer, Shari L.,(1995), The Myths of Motherhood, United States of America: Penguin Books.

Tong, Putnam Rosemarie, (2006), Feminist Though, Yogyakarta: Jalasutra

Wirdhana dkk, (2013), Buku Pegangan Kader BKR tentang Delapan Fungsi Keluarga

\section{Internet}

Badan Pusat Statistik, "Keadaan Angkatan Kerja di Indonesia", https://www.bps.go.id/ diakses tanggal 25 Oktober 2020

Komnas Perempuan, "Kajian Dinamika Perubahan di Dalam Rumah Tangga Selama Covid 19 di 34 Provinsi di Indonesia", https://www.komnasperempuan.go.i d diakses pada tanggal 17 Oktober 2020 